\title{
NOTES FROM THE FIELD
}

\section{Women-headed Households in Agriculture: Report from West Bengal, India}

\author{
Kuntala Lahiri-Dutt* and Itishree Pattnaik ${ }^{* *}$
}

The year is 2018, and we are walking through thick, wet clay, without any terra firma of the kind we are accustomed to. We are trying to access one of the hundreds of chars-sandy, low-lying river islands located where the Ganga, known locally as the Hooghly River, meets the Bay of Bengal. The mouth of the delta is known as the Sundarbans (or Sundarban in Bangla), created by the waters that flow through the land and the precious gift of mud they bring. The entire area is made of clayey silt, carried down from the mountains by the rivers over millennia. Sundarban is a dynamic landscape where the distinction between land and water is blurred and farming and fishing are inseparable in building the livelihoods of people.

We are going to meet women-heads of households from Amarabati, Shibpur, Bishalakshmipur, and Rajnagar Srinathgram villages in Fraserganj and Budhakhali gram panchayats in Namkhana block of Kakdwip subdivision of the South 24 Parganas district in West Bengal. We have been working with these women through a locally-based non-governmental organization (NGO) for some months. Our present purpose is to talk about recent changes in the social, economic, and physical landscapes in these villages, from where large numbers of men have migrated out to nearby cities and towns. Men have migrated to earn cash, to help families cope with the growing pressures on rural livelihoods, leaving women as de facto heads of households to farm the land. Men's outmigration is a feature seen in other parts of West Bengal and across India (Maity, Mazumdar, and Das 2018; Chandrasekhar, Sahoo, and Swaminathan 2020; Garikipati 2008).

\footnotetext{
* Crawford School of Public Policy, ANU College of Asia and the Pacific, The Australian National University. kuntala.lahiri-dutt@anu.edu.au

** Gujarat Institute of Development Research (GIDR).itipattnaik7@gmail.com

Copyright (C) Lahiri-Dutt and Pattnaik 2022. Released under Creative Commons Attribution (C) NonCommercial 4.0 International licence (CC BY-NC 4.0) by the author.

Published by Indian Society for Ecological Economics (INSEE), c/o Institute of Economic Growth, University Enclave, North Campus, Delhi 110007.
}

ISSN: 2581-6152 (print); 2581-6101 (web)

DOI: https://doi.org/10.37773/ees.v5i1.590 
In this note, we offer brief glimpses into the changing lives of rural peasant women. "Women-headed household" (WHHs henceforth) are defined as those households where farm-level decision-making is made primarily by women. A farming WHH may be led by a women farmer with a long-term migrant husband, a widow and/or abandoned wife, or someone whose husband is usually a peasant, but in most cases, is engaged in other jobs close to the village. The family of the woman may have some land (ownercultivator), she may cultivate someone else's land on rent (bhagchashi or sharecropper), she may work on someone else's land on a daily wage basis (agricultural labourer), or her situation might be a complex combination of these three basic categories. For example, a sharecropper can also be an owner-cultivator and even employ labour to work on her land. A WHH may also be involved in other community activities such as the preparation of mid-day meals, running crèches and day-care centres, food-for-work programmes, and other tertiary activities.

Our survey covered $100 \mathrm{WHHs}$ covering four villages. In addition to these women, we deployed ethnographic methods such as field observations, interviewing locally important pepole such as village elders, village council leaders (panchayat pradhans), and leaders of self-help groups whom we thought may be able to reflect on the recent changes in the rural landscape. Finally, we also held focus group discussions with village women to talk about their perceptions regarding the changing climate and its livelihood consequences for them. The result of these research processes was a combination of quantitative and qualitative data, generated through questionnaire-based surveys, and observations, interviews and discussions. We also used desk-based reviews of previous studies and secured data from secondary sources, including historical and geographical descriptions of the Kakdwip subdivision and its social context, economic situation, agricultural history, and population. This research was part of our study "Farmers of the Future: Challenges of a Feminized Agriculture in India" funded jointly by the Australian Research Council and the Indian Council of Social Science Research (Pattnaik and Lahiri-Dutt 2021).

The distance from Kolkata to Kakdwip town is only 80 kilometres, but the villages present a world that is utterly different from that of the metropolis. Poverty is acute and is very observable: in Namkhana block, about $48 \%$ of households fall below the poverty line (BPL) and 27\% of the population is from the Scheduled Castes. The mainstay of the rural economy is monsoonal aman paddy. Around $85 \%$ of villagers rely on such mono-crop agriculture, and annual production levels are much lower than the national average (2.225 tones/ha against the all-India average of 3.280 tones/ha). Moreover, the per capita land-holding and the average size of cultivated 
land in the block are both miniscule at 0.084 ha and 0.41 ha, respectively, as compared to the national average of 1.08 ha for small farmers in India (Government of India 2019).

The survey reveals that the average age for the surveyed woman heads of households is 45 years. A total of $56 \%$ were married, with living husbands, $36 \%$ were widowed, and the remaining $8 \%$ were divorced or single women at the time. The average size of the cultivated land owned by WHHs is 0.08 ha. The majority of WHHs (68\%) are unable to read or write, have a debt burden (as $71 \%$ of households have a loan to repay, usually to the local mahajan or moneylender, taken at a time of duress to tide over a financial crisis), and as many as $58 \%$ of them live in kuchcha houses made of mud. The annual average income of households is around ₹36,000 (income from various sources added together including food produced for own consumption), i.e., they are poorer than other households despite nearly half of them receiving some remittance irregularly.

Women's headship of households is higher in the Sundarbans than the rest of West Bengal (or even India) as a whole. This high headship is due to many factors: lack of economic opportunities leading to high rates of outmigration of men (evidenced by the fact that $64 \%$ of the surveyed households have someone who has migrated from the village); high rates of tiger attacks (there is one village locally known as "the village of widows" with only a handful of men); and environment-related, such as frequent flooding, increased frequency and strength of cyclones, riverbank erosion, and salinity, as saltwater poisons the soil, rendering the land unfit for farming. All these have a gendered impact, as they lead to the out-migration of men, and families are forced to diversify their livelihoods towards nonfarm activities.

Of all the women heads of households in farming, owner-cultivators form $47 \%$; in this group, $26 \%$ are exclusively owner-cultivators. Among the rest, $28 \%$ are agricultural labourers (those without any land to till) and another $28 \%$ are agricultural labourers as well as owner-cultivators/contract cultivators/sharecroppers/mortgage land cultivators. As noted earlier, most of the owner cultivators have only tiny pieces of land. Like in other parts of the country, in recent years, thika-khajana or contract cultivation has gained significance in the area and $25 \%$ of WHHs practice some kind of contractbased farming. The terms and conditions for thika-khajana vary; usually, the contract value for barsati chas (monsoon crop) is lower than that of kharati chas (kharif crop) and is highest for boro chas (winter cultivation). Many families put their land on bandbyaki-sud if they need money for an emergency such as someone's illness, or a child's marriage. In such cases of 
land mortgaging, the lender can take over the borrower's land for cultivation as soon as the borrower stops paying the interest on the loan.

On an average, agriculture contributes around 39\% to household incomes (income from agriculture is calculated by multiplying the crop production with the sold price). Most households take up other livelihood activities such as drying fish, fishing, and trading in rice to supplement their meagre incomes. About 23\% work for the Mahatma Gandhi National Rural Employment Guarantee Act (MNREGA) schemes, but the incomes generated are very low as they hardly get the opportunity to work under the scheme for more than 10-20 days. Quite a few (less than 10\%) women also work as domestic help or as attendants in hotels that serve the tourists who visit the nearby town. In general, most WHHs cultivate paddy/rice for their own consumption and the extra amounts are sold. In the salty, low-lying lands, not many other crops can be grown.

Despite the varying conditions among households, the dependency burden of women heads of households is uniformly high-each individual respondent has to provide for an average of 2 children and 0.3 elderly people. The children are generally young, with $85 \%$ of WHHs having children of school age.

WHHs feel that farming practices have changed in the last 10 or 15 years, primarily in the areas of ploughing, hybrid seed use, use of fertilizers, introduction of mechanized aid, type of labour, and technology. A total of 98\% feel that paddy yield has increased due to modern technology. They observed that leasing of land-i.e., contract-based farming-has increased. Traditionally, farming was a joint task shared by men and women, the latter assisting men by carrying out repetitive tasks and processing the paddy. We found that women are now taking the lead role in farming. The use of modern agricultural machinery has reduced manual labour, and many women aspire to own productive assets such as power tillers and shallow irrigation pumps.

Slightly over half $(56 \%)$ of the WHHs work as agricultural labourers, but only $28 \%$ are solely agricultural labourers, while the remaining are agricultural labourers as well as owner cultivators/contract cultivators/sharecroppers/mortgage land cultivators. This complexity reflects a local custom where most women contribute labour in cultivating the agricultural land of each other's families. They call this custom badla (return). Sharecropping has declined in the villages. The normal practice of sharecropping is if the cultivator bears all the costs of cultivation, they will get $75 \%$ of the yield and the owner will receive $25 \%$. In cases where the 
owner bears all the costs, the share is 50:50. There is a positive relationship between contract cultivation and the income from one bigha (0.13 ha).

Women's paid work as agricultural labourers and in other non-farm activities provides a somewhat better income for families as compared to working in their own fields and working in other's fields as badla. However, the local wage rates for agricultural labour are low (only about ₹70-80), and the number of days such jobs are available is meagre at only about 15-20 days per year. While work as agricultural wage labour provides some cash, it is not easy to find such work as most of women's labour is contributed for badla. Other non-farm jobs such as casual work in hotels and employment as domestic help provide better incomes, but those opportunities are limited and dependent upon seasons, distance of residence from main roads, and so on.

Yet, we found that women heading households in Sundarban are also increasingly involved in major decision-making within their families. It is not uncommon for them to make decisions regarding their children's education and household finances. However, major decisions, such as those concerning building a house and borrowing or lending money, are remotely controlled by men. Further, in most cases, major decisions related to farming and the sales and purchase of assets and major farm inputs tend to be taken by men over the phone.

There are exceptions, of course. Let us tell the story of Arati Baitalik (name changed for ethical reasons) is a 58-year-old widow who exemplifies our observations. Arati is a victim of cyclone Aila, which made landfall in the area in late May 2009. She owns 0.5 bighas of cultivating land in Uttar Shibpur village. However, she took a small loan from the local mahajan (lender) that she could not repay, and so the lender took her land as mortgage. Arati has two dependents, both school-going children, and she confidently spoke to us about her position within the family and community. Arati makes all the major household decisions but her workload is also huge. After performing her household duties, she fishes, works on her farm, and works on another farm as a part of badla. She is an agricultural labourer during the monsoon season, but for the rest of the year, she processes paddy purchased from the local market to sell in Kakdwip market. When we spoke with Arati about the difficulties in her life, she presented an optimistic outlook and firmly believed that her children will look after her.

Arati's case is exemplary also because most women get few opportunities to find livelihood opportunities other than farming. Even if she is literate, a woman usually has no training in farming, either traditionally from parents 
or from agriculture extension services. They do not receive credit as well; an overwhelming majority- $97 \%$ — told us that they have not received any agriculture-related aid or technical training from the government or any NGOs. However, many want these exposures; while interacting with us, women stated their aspiration to learn new methods of fishing and farming paddy. Some even expressed their interest in entering new income-earning work where the requirement of manual labour would be less. One woman was ready to open her own grocery store.

Overall, the study examined women's interests, priorities, and challenges in farming. Many of them observed that fishponds have changed due to an increase in silting, water pollution, and weed growth. Many were fearful of the rapidly changing environment and worried about obtaining a good harvest. The lack of irrigation, paucity of land, and rising incidence of pests and insects are the farming-related difficulties that they observed. These, combined with the inequities caused by gender roles, exacerbate the challenges for women farmers. The saline soil requires significant amounts of effort and investment that women from poorer households are unable to garner.

As we end this note, we might remind the readers of the fact that this area was the centre of a well-known peasant movement called the Tebhaga Andolan initiated by the Bangiya Pradeshik Kisan Sabha after the Bengal famine of 1943. Tebhaga Andolan aimed to secure for sharecropper peasants a better deal within the existing land tenure. The movement led to the enactment of the Bargadari Act of 1950, which was incorporated in the West Bengal Land Reform Act 1956 (as Chapter III). The act legally recognized the sharecroppers' right to two-thirds of the produce when they supplied the necessary inputs. Unfortunately, as we saw, the act could not change the circumstances of smallholder farmers and sharecroppers in the region. Studying the area seventy years later, we felt that not much has changed for poor peasants, except that they are now under even more pressure as the climate has also turned hostile towards them.

Women are caught under the multi-faceted pressures exerted by a combination of social, economic, and physical forces in the Sundarbans. On the one hand, male outmigration has increased their work burdens. On the other, the changing climate and declining farm incomes have posed unforeseen challenges to women. Trudging through the mud, we felt a sense of urgency and helplessness and the need for immediate measures. There is, however, no easy prescription that can be offered as the solution; perhaps we need more detailed investigations to understand how each of the external forces acts in conjunction with the local context and develop 
policies that are tailored to the region and accepted by the women who bear most of the brunt.

\section{REFERENCES}

Chandrasekhar, S, Soham Sahoo, and Hema Swaminathan. 2020. "Seasonal Migration and Feminization of Farm Management: Evidence from India". Working Paper no. 630. Bangalore: Indian Institute of Management. https://doi.org/10.2139/ssm.3745554

Garikipati, Supriya. 2008. "Agricultural Wage Work, Seasonal Migration and the Widening Gender Gap: Evidence From a Semi-Arid Region of Andhra Pradesh." The European Journal of Development Research 20 (4), 629-648. https://doi.org/10.1080/09578810802464870

Government of India. 2019. Agricultural Statistics at a Glance 2018. New delhi: Ministry of Agriculture \& Farmers Welfare, Department of Agriculture, Cooperation \& Farmers Welfare, and Directorate of Economics and Statistics. Government of India.

Maity, Kingsuk, Debasis Mazumdar, and Pinaki Das. 2018. "Male Out-Migration and its Impact on Women Empowerment in West Bengal." Economic Affairs 63 (2): 459-467. 10.30954/0424-2513.2.2018.23

Pattnaik, Itishree, and Kuntala Lahiri-Dutt. 2021. "Do Women Like to Farm? Evidence of Growing Burdens of Farming on Women in Rural India." The Journal of Peasant Studies. https://doi.org/10.1080/03066150.2020.1867540 